\title{
ドリーの遺産
}

\section{Dolly's Legacy}

\author{
Nature Vol.445(795)/22 February 2007
}

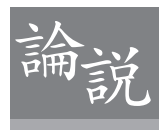

この 10 年間で哺乳類のクローン作製技術は前進したが、社会的に重要な諸問題は今もって解決されていない。それでも 生殖目的のヒトクローン作製は不可避だと考えられる。

今から 10 年前、Natureから恒例の発表解禁日付きプレスリリー スによって、ある論文掲載の予告を 1 週間前に受けた報道関係 者たちは、久々の超ホットな科学ニュースに色めき立ち、報道の 準備を進めていた。このプレスリリースには、ヒツジの成体細胞 からクローン個体を作製したことが告示されていた。ところが英 国の日曜紙The Observerの記者が、このニュースをある映画制 作会社から入手して、発表解禁日を待たずに報道してしまった。 これに憤慨した他紙の編集部は、遅れまいとして緊急報道体制 を敷いた。「クローン人間を作って大勢の独裁者を作り出す可能 性があるのだから、最大級の注目が集まるはずだ」という見解を The Observer紙は示し、実際その通りになった。報道から数日も 経たないうちに、米国大統領、EC委員長、ローマ法王をはじめ さまざまな人々が、全面禁止とまではいかないまでも、クローン 作製研究に対する法的規制の見直しをよびかけたのである。

当時の世の中は、このような議論をするための準備がまっ たくできていなかった。その前年にはすでに、ヒツジで肧細 胞からのクローン作製に成功したとする研究論文がNatureで 発表されて抢り、同じ号に揭載された News \& Views の論評で Davor Solter 、、成体細胞からのクローン作製技術の「使い 方について検討を始めたほうがよさそうだ」と警告した。し かし他の研究者は、このような見解に否定的な態度を示すか、 あるいはまだ何年も先の話だと予想した。

クローン技術でドリーを作製した研究チームは、その研究内 容を外部に漏らさないようにしていた。しかし、肧細胞から のクローン作製に際したマスコミとの対応で教訓を得て、PR 会社を起用し、研究成果の公表後に放映するテレビ用ドキュメ ンタリーの制作に協力して取り組んでいた。このような対応 は実を結ばなかったが、その姿勢は他の研究者にとって今で も手本となるものだ。研究者とその所属研究機関は、画期的 な研究成果を発表する場合、幅広い層の受け手を想定し、そ の研究の背景と意義についての考え方をマスコミに伝え、な おかつウェブサイト上で発表する責任を負っている。本誌を始 めとするジャーナル各誌も、このように研究の背景説明を伝 えるうえで、より多くの貢献ができることは間違いない。

クローン作製研究は、その後どう推移してきたのだろうか。 Nature 2007年 2 月 22 日号のp. 800 で解説したように、多く の研究が体細胞核の移植と幹細胞技術を組み合わせることに 重点を置くようになった。ドリーのニュースが発表された当
時、これが畜産に及ぼす影響についてはほとんど関心がもた れなかった。ところがその後、まさにこの分野で生殖目的の クローン作製技術が大きく進歩し、十数種の哺乳類のクローン が作り出された。研究の進展度をはかる尺度の1つが米国食 品医薬品局（FDA）によるリスク評価（www.fda.gov/cvm/ CloneRiskAssessment.htm参照) で、現在、これについて公 の協議が行われている。

FDA の報告書は、安全性については総じて楽観的だが、重 要な 1 点について進展がみられないことを指摘している。そ れは、哺乳類のクローン作製の効率がいまだに低い点だ。基 䃈生物学研究にとっての課題が、ここに明確に示されている。 研究分野の1つとして、例えばエピジェネティクスがある。こ 机にって、クローン作製の場合にDNAについている化学的 マーカーのどれが変化するのか、そして、クロマチン構造にど んな変化が生じ、そ机が通常の生殖とどのように異なるのか を調べる。この分野の研究の進展は期待していいだろう。ま た、米国の消費者はクローン動物の作製に不安を感じてはい るものの、動物クローン作製技術の応用に反対する可能性は 低いと考光られ、ましてやこの技術のかかわった製品に対す る反対などは起こりそうにない。

これに対し、全世界的に許されないと考光られているのが、 生殖目的でのヒトクローン作製で、これはいうなれば「時間を 隔てて生まれる一卵性双生児」を作り出すことである。これに 関する議論の大半を占めているのが、尊厳と安全性という2つ の問題である。クローン作製技術で生まれた子どもが、ある目 的のための手段としてだけでなく、1人の人間としての権利を 認められるのであれば尊厳は損なわれないという点では、意見 の一致が得られている。しかし、クローン人間作製のリスクが 倫理的に許容されるくらい十分に小さくなるまで十分にクロー ン技術の理解が進むか、という点では意見が分かれている。

この論争は、すばやい研究禁止措置によって封印されてし まったと思わ机ているかもしれない。しかしエピジェネティク スや発生に関する研究の進歩は不可避であり、不妊や遺伝病 への対処法としてクローン作製技術しか残されていない人々 は、この技術の活用をより強く求めていくだろう。生殖目的 でのヒトクローン作製は、全体として肯定的な倫理上の動機づ けが得られれば、生物学的に何か未知の大きな障害となる問 題が生じない限り、まず間違いなく実現されるだろう。 